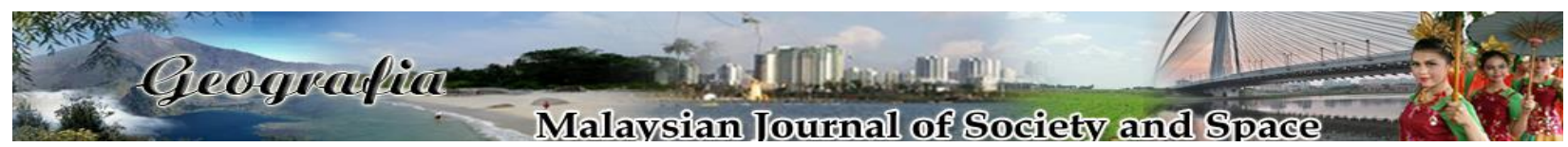

\title{
Pantai pelancongan mesra keluarga dan tuntutan persekitaran fizikal semulajadi daripada lensa pelancong tempatan
}

\author{
Habibah Ahmad, Hamzah Jusoh, Noradila Azhar, Kadaruddin Aiyub, Nurul Fadhiah Mohidin, \\ Mohd Fuad Mat Jali \\ Pusat Pembangunan, Sosial dan Persekitaran, Fakulti Sains Sosial dan Kemanusiaan, \\ Universiti Kebangsaan Malaysia \\ Correspondence: Habibah Ahmad (email: ha@ukm.edu.my)
}

Received: 15 November 2019; Accepted: 22 November 2019; Published: 25 November 2019

\begin{abstract}
Abstrak
Pelancongan pantai merupakan aktiviti tumpuan pelancong antarabangsa dan tempatan di kebanyakan negara yang mempunyai keistimewaan tarikan ini. Di Malaysia, pelancongan pantai tidak terkecuali daripada mendapat perhatian pelancong domestik, termasuk pelancong keluarga. Salah satu pantai pelancongan yang terkenal dalam kalangan segmen ini ialah Pantai Batu Ferringhi, Pulau Pinang. Pantai ini mempunyai kelebihan persekitaran semula jadi sebagai tarikan kepada para pelancong keluarga. Ini adalah seiring dengan tuntutan pelancongan lestari yang memerlukan persekitaran fizikal semula jadi menjadi sumber lestari dan dapat dihayati oleh pengunjungnya. Walau bagaimanapun pilihan keluarga terhadap pantai mesra keluarga berdasarkan persekitaran semula jadi pantai masih belum terserlah. Makalah ini bertujuan untuk mengenalpasti apakah cirian persekitaran fizikal semula jadi yang menjadi penentu kepada pelancong keluarga dalam membuat kunjungan ke Pantai Batu Ferringhi. Kajian ini adalah berasaskan soalselidik yang telah diedarkan kepada 300 responden keluarga di pantai tersebut. Hasil kajian mendapati pelancong keluarga melakukan aktiviti rekreasi pantai yang santai berbanding lasak, dan motif kedatangan ialah meluangkan masa dan dapat bersama anak-anak dan ahli keluarga. Dapatan kajian mengesahkan persekitaran fizikal semulajadi pantai menjadi sebahagian daripada penentu pemilihan pantai pelancongan mesra keluarga. Ini kerana persekitaran ini tidak menghalang aktiviti utama di pantai peranginan ini. Beberapa cadangan dikemukakan untuk penambahbaikan; antaranya jaminan pantai yang bersih dan luas, air laut yang tidak tercemar, jaminan keselamatan pantai dan landskap pantai yang terpelihara. Kesimpulannya, persekitaran fizikal semula jadi berperanan penting dalam menarik minat pelancong keluarga untuk melancong ke pantai peranginan khususnya di Pantai Batu Ferringhi.
\end{abstract}

Kata kunci: cirian dan aktiviti pelancong, pelancongan pantai, pelancong keluarga, persekitaran fizikal 


\title{
Family-friendly beach tourism and the demands for the natural physical environment from local tourists' lenses
}

\begin{abstract}
Beach tourism is an activity usually consumed by the international and local tourists in most of the countries that possess the specialty of this natural attraction. In Malaysia, beach tourism is not an exceptional to domestic tourists, including family tourists. One of the popular beaches is the Batu Ferringhi Beach, located in the island of Penang. The beach is claimed to have the natural environment appeals as the key attraction for family visitors/travelers. However, until today, the extent of the families making choices to visit beaches depending on the natural beach environment remained unclear. Realising that this issue should be attempted to provide sustainable beach tourism, this paper aims to uncover the natural environmental factors that determine the choice of the family segment in making their visit to this destination, particularly to the Batu Feringghi Beach. A total 300 family respondents were successfully interviewed using questionnaires. The findings show that family members favour casual beach activities compared to highly-actived activities, and their motives include spending time and being together with children and family members. The fndings has proven that the physical environment of the beach is the key choice for family friendly beach destination. This factor does not create barriers for their family beach activities. Recommendations include assurance of clean and wide beach, unspoiled seawater, beach security and preserved landscape. In conclusion, the natural beach environment has played an important role in attracting visitors /family travelers to visit beaches, particularly to the Batu Ferringhi Beach.
\end{abstract}

Keywords: charaters and tourist activities, beach tourism, family tourists, physical environment.

\section{Pengenalan}

Pelancongan pantai adalah salah satu aktiviti tradisi dalam kalangan masyarakat bandar di negara-negara maju semasa melancong dalam dan luar negara, dan ini menjadi ikutan kepada penduduk di negara sedang membangun (Honey \& Krantz, 2007; Onofri \& Nunes, 2013). Pelancongan persisiran pantai ini dilaporkan sebagai segmen terbesar dalam industri pelancongan dunia dan trend ini dijangka berterusan berikutan peningkatan permintaan terhadap pantai dan alam semulajadi dalam kalangan penduduk bandar (Hall, 2001; Wolch \& Zhang, 2004).

Di Malaysia, aktiviti pelancongan pantai sudah menjadi sebahagian daripada gaya hidup penduduk (Habibah, 2002; Jamaludin, 2009). Jika pada zaman British aktiviti pelancongan pantai menjadi amalan elit pemerntah, kini, pantai menjadi sebahagian daripada aktiviti percutian penduduk di negara ini. Menurut Habibah (2007) seawal tahun 1980-an, aktiviti kunjungan ke pantai peranginan di Malaysia telah berlaku dan kunjungan mereka juga dipengaruhi oleh keindahan semula jadi pantai. Pantai yang menjadi tumpuan pelancong adalah pantai yang bersih, selamat dan selesa untuk pelbagai aktiviti (Johan dan Mohamad Zaki, 2011; Johan et al., 2012). Keindahan pantai yang menyamankan dan mempesonakan juga tidak terkecuali daripada 
dapat membantu menarik pelancong tempatan dan luar negara untuk memilih pantai sebagai destinasi utama.

Ramai sarjana Barat berpandangan kawasan pesisir pantai adalah sebuah kawasan yang sangat penting sebagai destinasi pelancongan (Hall, 2001; Honey \& Krantz, 2007). Sehubungan itu, pantai menjadi tarikan kepada pelancong antarabangsa dan pelancong domestik, termasuk pelancong berkeluarga. Dalam konteks ini, pantai bagi pihak pengurusan, memerlukan satu pendekatan yang bukan sahaja menghitung keuntungan tetapi juga sensitif kepada keperluan para penggunanya (Williams et al., 1993; Minuchin, 1985; Cicin-Sain et al., 1995).

Di sesetengah negara maju, penarafan dan penjenamaan pantai pelancongan yang bersifat mesra pelancong telah menjadi sebahagian daripada pendekatan secara lestari (Dormnish et al., 2015). Walau bagaimanapun, penggunaan pantai pelancongan mesra keluarga mendapat tentangan daripada sesetengah pelaksana. Ini kerana kesesuaian konsep keluarga semakin dipertikaikan ekoran ciri-ciri keluarga kini telah banyak mengalami peubahan (Staines \& Ozanne-Smith, 2002). Penggunaan family friendly beach dengan kriteria terperinci, terbahagi kepada persekitaran semulajadi dan buatan manusia akan membolehkan pihak pengurusan menyelia dan menambahbaik kualiti pantai. Bagi perancang dan pihak pengurusan pantai, persekitaran semula jadi bukan sekadar jaluran pantai dan air laut semata-mata, tetapi ia menyentuh landainya pantai, air laut yang bersih dan berombak, tiada pencemaran dan landskap pantai yang menarik (Roca et al., 2008).

Di Malaysia, walaupun aktiviti pelancongan pantai telah sebati dengan gaya hidup masyarakat setempat (Jamaluddin, 2009; Habibah, 2007), namun, tiada inisiatif yang komprehensif untuk meneliti keperluan memberikan penarafan pantai pelancongan mesra keluarga terutama dalam konteks penggalakan pelancongan domestik. Setakat ini, pantai Port Dickson dan Pantai Chenang telah menggunakan jenama pantai keriangan keluarga sebagai asas untuk menarik kedatangan pelancong. Inisiatif berteraskan keriangan keluarga ini sebenarnya merupakan strategi pembangunan terangkum dalam Rancangan Malaysia ke-11. Penekanan kepada persekitaran semula jadi seolah-olah tidak diutamakan oleh para pengunjung, sedangkan sensitiviti awam terhadap isu pantai dan air laut yang kotor, pantai tidak diurus dengan baik semakin tinggi. Sehubungan itu, inisiatif untuk meneliti isu ini dalam agenda kelestarian pelancongan di negara ini adalah bertepatan dan relevan.

Salah satu pantai popular ialah Pantai Batu Feringgi, yang terletak di Pulau Pinang. Pantai ini selain menjadi tumpuan pelancong antarabangsa, ia juga menjadi tumpuan pelancong domestik, terutama dalam kalangan pelancong keluarga. Menyedari bahawa pantai ini bersesuaian sebagai pilihan keluarga untuk bercuti dan beriadah, langkah untuk menganalisis kepentingan persekitaran semula jadi dalam agenda pantai pelancongan mesra keluarga adalah sangat relevan. Pantai ini pernah dilanda tsunami, namum, ia masih popular sebagai pantai peranginan utama di Pulau Pinang (Kerajaan Negeri Pulau Pinang, 2013).

Sehubungan itu, makalah ini bertujuan untuk menganalisis persekitaran fizikal semulajadi sebagai asas penarafan pantai pelancongan mesra keluarga berdasarkan perspektif pelancong domestik. Perbincangan makalah ini didasarkan daripada dapatan survei ke atas 300 pengunjung/pelancong pada tahun 2018. Makalah ini diharapkan dapat mengisi lompang penyelidikan tentang pembentukan pantai pelancongan mesra keluarga di negara ini dengan tumpuan mendalami empat komponen persekitaran alam semula jadi daripada lensa pelancong keluarga. 


\section{Tinjauan literatur}

\section{Pantai dan pelancongan pantai}

Pantai merupakan satu sistem sosial ekologi di mana dimensi fizikal, ekologi, sosial dan ekonomi berinteraksi untuk menyediakan beberapa fungsi dan perkhidmatan yang membawa kepada peningkatan kesejahteraan manusia (Lozoya et al., 2014). Ia merangkumi pelbagai perkhidmatan ekosistem seperti perlindungan pantai, penapisan air, tanah, makanan, pelancongan dan rekreasi. Walaupun sistem ini dapat menyediakan beberapa fungsi pelindungan, rekreasi dan semulajadi, pilihan masih terhadap rekreasi secara tradisional menjadi keutamaan oleh pihak berkenaan (Botero et al., 2013; Jędrzejczak, 2004).

Di seluruh dunia, pantai merupakan salah satu tempat paling popular yang digunakan untuk berekreasi dan mengisi masa lapang oleh semua lapisan masyarakat dan turut menjadi zon gabungan arus pantai, gelombang dan pasang surut. Oleh itu, kawasan persisiran pantai dan pulau telah menjadi tumpuan para pelancong asing mahupun tempatan sebagai destinasi pelancongan utama mereka (Roca et al., 2008; Cervantes et al., 2015, Cutter et al.,1979).

Pelancongan pantai merujuk kepada aktiviti pelancongan yang dilakukan di persisiran pantai. Aktiviti pelancongan pantai ini telah menyerlahkan penggunaan sumber iaitu pantai dan air laut. Pelbagai aktiviti senggang lasak atau santai dapat dilakukan dan ini termasuk bermain pasir dan pantai, beristirehat, mandi manda, menaiki banana boat, bercamping dan memancing. Aktiviti ini menunjukkan bahawa pelancongan pantai merupakan aktiviti santai sehingga aktiviti lasak berasaskan sumber yang terdapat di kawasan pinggir pantai (Botero et al., 2013; James, 2000).

Sementara itu, kajian tentang pelancongan pantai di Malaysia juga mendapat perhatian sarjana tempatan, namun terhad di beberapa pantai terpilih, termasuk pantai Port Dickson, Pantai Chenang, Pantai Cahaya Bulan (Habibah \& Hamzah, 2018; Mohd. Anuar, 2009; Johan dan Mohamad Zaki, 2011; Johan Afendi et al., 2012; Jamaluddin, 2009; Ramali, 2017; Mohd Azlan et al., 2012). Kedatangan pelancong sering dikaitkan dengan faktor alam semulajadi, daya tampungan dan faktor manusia selain faktor budaya seperti makanan dan kesenian setempat (Ahmad Nazrin et al., 2014).

\section{Pantai pelancongan dan pantai pelancong keluarga}

Pantai pelancongan dirujuk kepada ruang fizikal yang dibenarkan dan dibangunkan untuk tujuan menggalakkan aktiviti pelancongan berasaskan sumber pantai dan kawasan persisirannya. Kaedah ini membolehkan cirian pantai melibatkan unsur fizikal pantai dan pesisirannya dipantau agar kawasan ini menepati keperluan sebagai destinasi pantai pelancongan.

Di beberapa negara maju, pengkategorian pantai pelancongan terbahagi kepada beberapa kriteria mengikut tahap pemajuan pantai tersebut. Roca et al. (2008) menganjurkan empat jenis pantai iaitu pantai berstatus maju dan terbandar, pantai yang sederhana majunya, pantai luar bandar dan pantai rezab yang secara sengaja tidak dimajukan sebagai kawasan tumpuan pelancong. Pantai yang tidak dimajukan untuk tujuan rekreasi dianggap sebagai pantai pemelihaaran dan perlindungan. Pengkelasan pantai sebegini membolehkan para pengunjung mengetahui sifat fizikal pantai, air laut dan kualiti pantai.

Sementara pantai pelancongan mesra keluarga merujuk kepada penarafan sesebuah pantai

itu menyediakan keistimewaan kepada pengunjung keluarga. Di Australia, inisiatif untuk 
memperincikan keperluan keluarga telah membolehkan cirian persekitaran semula jadi pantai dan air menepati kehendak pengunjung keluarga (Staines \& Ozanne-Smith, 2002). Ini termasuk pantai yang landai dan pasir yang memutih telah menggalakkan permainan istana pasir dalam kalangan keluarga. Pengetahuan tentang rumpai laut yang tidak sesuai dengan kanak-kanak juga dapat mengelakkan keluarga mengambil risiko untuk mandi manda dan sebagainya.

\section{Aktiviti pelancongan pantai di Malaysia}

Di Malaysia, aktiviti pelancongan pantai juga mendapat perhatian sarjana tempatan (Harifah et al., 2015; Mohd. Anuar, 2009; Mohd Azlan et al., 2012). Bagimanapun, karya ini agak terbatas, dan terdapat tiga sisi utama perspektif aktiviti pelancongan pantai di negara ini. Pertama, kajian menjurus kepada profil pengunjung, kepuasan dan kualiti pantai. Kualiti pantai sering menekankan perkhidmatan buatan manusia walaupun kecantikan pantai semulajadi diberikan penekanan.

Kedua, kajian tentang aktiviti pelancongan ini dikaitkan dengan aktiviti berasaskan air laut, secara aktif dan pasif. Aktiviti aktif merujuk penggunaan sumber air laut dan pantai dengan pergerakan fizikal dan kecergasan pengunjungnya seperti aktiviti mandi manda, menaiki banana boat, camping dan permainan bola tampar pantai. Sementara aktiviti pasif merujuk kepada aktiviti santai, beristerehat, menikmati panorama pantai, bersiar-siar dan makan-makan.

Ketiga, aktiviti pelancongan pantai kini diperluaskan kepada acara-acara yang dikendalikan oleh pihak pemegang taruh seperti badan kerajaan, swasta dan badan bukan kerajaan. Pantai menjadi tumpuan kepada acara pembersihan pantai, larian amal dan sukaneka rakyat. Bagaimanapun pengamatan tentang aktiviti ini jarang dikaitkan dengan persekitaran semulajadi dan persekitaran buatan manusia.

Keempat, kajian tentang aktiviti pelancongan pantai dikaitkan dengan daya tampung dan kesan kepada penduduk setempat. Menurut Kadaruddin (1997), kawasan persisir pantai merupakan kawasan berpotensi dan menerima tekanan pembangunan berkaitan dengan pelancong, perindustrian, pertanian, dan perikanan. Oleh itu, pantai menjadi tarikan pengunjung dan turut memberi kesan kepada alam sekitar.

\section{Persekitaran fizikal semulajadi}

Persekitaran fizikal semulajadi disifatkan sebagai asas penentuan pilihan pengunjung apabila mereka mahukan sesuatu aktiviti pantai. Dalam tinjauan tentang persekitaran fizikal semulajadi Roca et al. (2008) telah menggariskan beberapa angkubah pantai, air laut, panjang pantai dan landskap pantai. Daripada karya pustaka, persekitaran semulajadi berkait rapat dengan indikator pantai seperti panjang dan luas pantai, kelandaian pantai, jenis pasir dan pemandangan atau landskap pantai (Ergin et al., 2006; Cervantes et al., 2008; Sarda et al., 2009). Cutter et al. (1979) mendapati bahawa kebersihan air dan pantai merupakan ciri utama kepada pemilihan oleh pengunjung pantai, diikuti oleh ciri-ciri semula jadi pantai tersebut. Malahan pengetahuan tentang laluan arus balik (rip current) akan memastikan pihak pengurusan pantai memantau keselamatan pengunjung pantai ketika berenang (Dalrympe et al., 2011; Houser et al., 2015).

Williamson et al. (2012) dan Houser et al. (2015) mendapati bahawa pilihan lokasi untuk berenang menjadi penyumbang utama kepada risiko keselamatan dan kejadian lemas di pantai. Aktiviti berenang di kawasan strategik yang telah ditandakan dengan bendera keselamatan, papan tanda keselamatan dan mempunyai pengawal pantai adalah pilihan paling selamat 
pengunjung pantai. Ini kerana kawasan pantai terlibat dalam kawasan pemerhatian dan pemantauan.

\section{Metodologi dan kawasan kajian}

\section{Kawasan kajian}

Kajian ini dilakukan di Pantai Batu Ferringhi, Pulau Pinang yang terletak di sepanjang pantai utara Pulau Pinang dan kira-kira 11 km (6.8 batu) dari barat laut George Town. Pantai ini merupakan kawasan peranginan utama di Pulau Pinang, dan ia menawarkan pelbagai aktiviti riadah kepada para pelancong. Rajah 1 menunjukkan bahagian yang bertanda warna biru sebagai kawasan kajian iaitu pantai Batu Ferringhi, Pulau Pinang. Kawasan kajian meliputi kawasan permulaan pantai dari Cinta Sayang Resort sehingga Hard Rock hotel. Batu Ferringhi mempunyai lokasi yang strategik dan mudah untuk dikunjungi (Portal Penang Global Tourism, 2018).

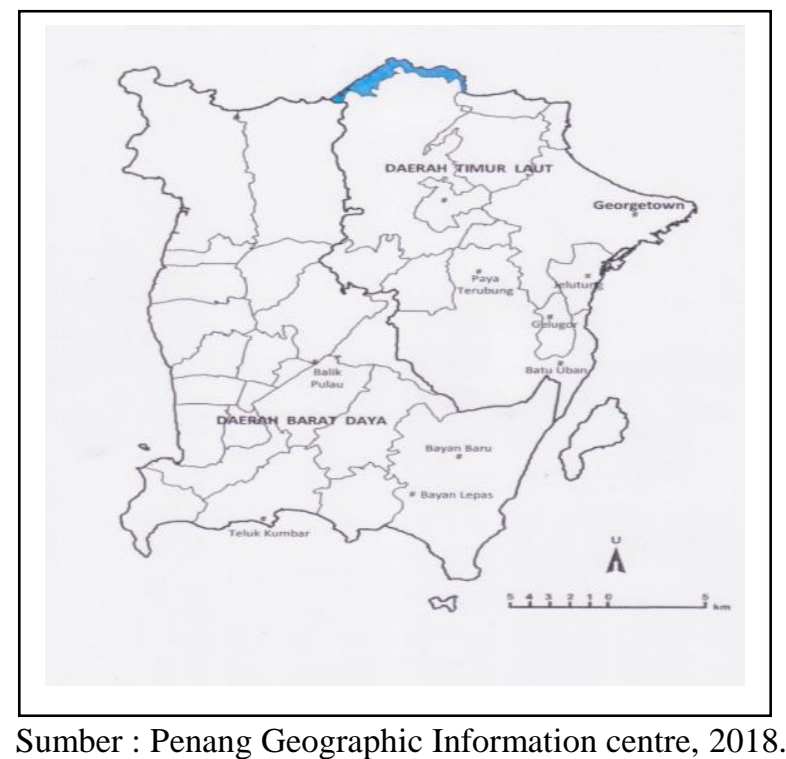

Rajah 1. Peta kawasan kajian

\section{Pengumpulan dan analisis data}

Makalah ini menggunakan data primer yang dikutip melalui pengedaran soal selidik. Pengedaran soal selidik kepada pengunjung/pelancong berkeluarga di Pantai Batu Ferringhi, Pulau Pinang dilakukan pada bulan Jun dan Julai 2018. Semasa sesi soal selidik, responden juga ditanya melalui soalan terbuka tentang kelebihan dan kekurangan persekitaran fizikal semulajadi, buatan manusia dan sektor sebagai soalan keseluruhan kajian tentang pantai mesra keluarga. Bagaimanapun, kajian ini hanya menggunakan bahagian yang berkisar kepada persekitaran fizikal semula jadi dalam membentuk pantai pelancongan mesra keluarga.

Pembentukan soal selidik bagi kajian ini dipandu oleh kajian-kajian lepas sarjana Barat terutama daripada Roca et al. (2008) dan Staines \& Ozanne-Smith, (2002). Bagi persekitaran 
fizikal semula jadi, empat komponen utama dan aspek-aspek berkaitan diperincikan. Satu kajian rintis dilakukan sebelum pengedaran soal selidik ke atas 300 pelancong/pengunjung keluarga dilaksanakan. Kaedah pemerhatian turut dilakukan di sekitar pantai untuk mengenalpasti cirian dan aktiviti pengunjung serta mengenalpasti faktor pemilihan pengunjung pantai terhadap faktor fizikal yang ditawarkan di sekitar pantai Batu Ferringhi.

Dari segi teknik penganalisian, kajian ini menggunakan kaedah kuantitatif. Data dianalisis melalui perisisan Statistikal Package For Sosial Science (SPSS) versi 23. Analisis deskriptif secara kekerapan dan peratusan dapat digunakan untuk menerangkan mengenai latar belakang pelancong. Bagi mengetahui pilihan ke atas cirian fizikal pantai, skor min hasil daripada respons pelancong ke atas empat komponen cirian tersebut digunakan.

\section{Dapatan dan perbincangan}

\section{Latar belakang responden}

Kajian ini telah mendapat maklum balas daripada 300 pelancong tempatan. Berdasarkan Jadual 1, sebanyak 56.0\% (168) terdiri daripada pelancong perempuan dan 44\% (132) lagi adalah pelancong lelaki. Kedua-dua kategori responden ini mewakili keluarga masing-masing untuk menjawab kajiselidik ini. Sebagai perempuan, mereka terdiri sama ada sebagai isteri, ibu atau anak perempuan dalam sesebuah keluarga manakala sebagai lelaki, mereka terdiri sama ada sebagai bapa, suami atau anak lelaki.

Jadual 1. Demografi pengunjung

\begin{tabular}{llcc}
\hline Aspek & & Bilangan & Peratus \\
\hline Jantina & Lelaki & 132 & 44.0 \\
Umur & Perempuan & 168 & 56.0 \\
& $17-25$ & 164 & 54.7 \\
& $26-35$ & 90 & 30.0 \\
& $36-45$ & 25 & 8.3 \\
& $46-55$ & 17 & 5.6 \\
Bangsa & $56-60$ & 4 & 1.3 \\
& Melayu & 243 & 81.0 \\
Taraf Pendidikan & Cina & 28 & 9.3 \\
& India & 47 & 9.0 \\
& Sekolah Menengah & 74 & 24.7 \\
& Diploma & 101 & 33.7 \\
Sektor Pekerjaan & Ijazah Pertama & 122 & 40.6 \\
& Master/Phd & 3 & 1.0 \\
& Kerajaan & 43 & 14.3 \\
& Swasta & 140 & 46.7 \\
& Pelajar & 80 & 26.7 \\
Datang dengan siapa & Tidak Bekerja & 37 & 12.3 \\
& Suami-isteri & 37 & 12.3 \\
& Suami, isteri dan anak-anak & 100 & 33.3 \\
& Keluarga besar & 96 & 32.0 \\
& Keluarga besar (formal) & 67 & 22.3 \\
\hline
\end{tabular}

Sumber: Data lapangan, 2018 
Dari segi umur, responden paling ramai adalah dalam kategori umur 17-25 tahun iaitu $54.6 \%$ (164). Hal ini kerana rata-rata keluarga datang bersama anak-anak atau ahli keluarga yang masih muda. Ini diikuti oleh responden yang berumur 26-35 tahun iaitu sebanyak 30\% (90). Selebihnya responden yang berumur dalam tiga kategori iaitu 36-45 tahun, 46-55 tahun dan 5660 tahun masing-masing kecil bilangannya iaitu $8.3 \%$ (25), 5.6\% (17) dan $1.3 \%$ (4) sahaja. Pelancong berbangsa Melayu paling ramai memberikan kerjasama iaitu $81.0 \%$ (243), diikuti responden berbangsa India 9.0\% (47) dan bangsa Cina 9.3\% (47) sahaja.

Hampir kesemua pelancong memiliki pendidikan, dengan sepertiganya atau $33.7 \%$ (122) responden memiliki kelulusan di peringkat ijazah pertama, diikuti 33.7\% (101) responden berkelulusan diploma. Hanya $24.7 \%$ (74) responden berpendidikan di peringkat sekolah menengah dan hanya 1.0\% (3) memiliki ijazah di peringkat Master/Phd. Para responden terdiri daripada pekerja pelbagai sektor, dengan mana pekerjaan swasta adalah paling ramai iaitu $46.7 \%$ (135), dan sektor kerajaan 14.3\% (43). Sementara itu sebanyak 26.7\% (80) masih belajar dan dan selebihnya $12.3 \%$ (37) sebagai suri rumah, golongan bersara dan penganggur.

Para pelancong juga terdiri dalam semua jenis keluarga. Paling menonjol adalah pelancong daripada keluarga asas atau nuklears yang membentuk lebih daripada sepertiga responden kajian (33.3\%). Ini diikuti segmen keluarga besar yang bukan sahaja terdri daripada pasangan suami dan isteri dan anak-anak tetapi juga merangkumi ahli keluarga lainnya iaitu sebanyak $32.0 \%$ (96). Paling sedikit terdiri daripada pasangan suami-isteri iaitu hanya $4.7 \%$ (14) daripada keseluruhan responden kajian.

\section{Tujuan mengunjungi pantai}

Dalam kajian ini, terdapat pelbagai tujuan kenapa para pelancong keluarga mengunjungi pantai Batu Ferringi. Berdasarkan jadual 2, tujuan utama ialah menghabiskan masa lapang bersama keluarga iaitu 55.0\% (165), ini diikuti oleh tujuan ingin mengenali destinasi sebanyak 37.3 (112). Bagi tujuan rekreasi dan sukan air pula, sebanyak 33.3\% (100) bersetuju aktiviti ini mendorong mereka ke sini. Sebanyak 59\% (19.7) memilih berkunjung ke pantai sebagai hobi melancong bersama keluarga dan $18.3 \%$ (55) lagi memilih pantai ini kerana terdapat acara sukan/hari keluarga tempat kerja. Terdapat juga tujuan lain antaranya ialah menyambut hari jadi, iaitu 3.0\% dan atas minat mengambil gambar, mencari kepelbagaian makanan dan bercuti sambil bekerja yang masing-masing hanya $1 \%$ sahaja.

Jadual 2. Tujuan utama

\begin{tabular}{lcc}
\hline Tujuan utama & Bilangan & Peratus \\
\hline Rekreasi dan sukan air & 100 & 33.3 \\
Ingin mengenali destinasi & 112 & 37.3 \\
Menghabiskan masa lapang bersama & 165 & 55.0 \\
keluarga & & \\
Pantai berhampiran rumah/kediaman & 55 & 18.3 \\
Hobi melancong bersama keluarga & 59 & 19.7 \\
Acara sukan/hari keluarga tempat kerja & 35 & 11.7 \\
Lain-lain & & \\
$\quad$ Minat mengambil gambar & 1 & 0.3 \\
$\quad$ Mencari kepelbagaian makanan & 1 & 0.3 \\
$\quad$ Bercuti smbil bekerja & 1 & 0.3 \\
Menyambut hari jadi & 9 & 3.0 \\
\hline
\end{tabular}

Sumber: Data lapangan, 2018 
Sementara itu aktiviti utama pelancong semasa di pantai ini ialah mengambil angin kerana aktiviti ini memperoleh sebanyak 52.3\% (157) daripada persetujuan tentang aktiviti utama ke Pantai Batu Ferringhi (jadual 3). Ini diikuti oleh 50.7\% (152) responden yang lebih gemar 'berehat' semasa berada di pantai. Sebanyak 46.0\% (138) responden memilih aktiviti berkelah sebagai aktiviti utama dan aktiviti riadah/bermain sukan air laut adalah sebanyak 36.0\% (108). Bagi mereka, pantai ini memanjang dan mudah untuk pengunjung memilih tempat untuk berkelah bersama-sama ahli keluarga. Bagaimanapun sebahagian kecil $7.0 \%$ (21) responden memilih menggabungkan kunjungan ini dengan 'tugasan kerja' kerana mengambil kesempatan untuk berada di pantai Batu Ferringhi.

Jadual 3. Aktiviti utama

\begin{tabular}{|c|c|c|}
\hline Aktiviti Utama & Bilangan & Peratus(\%) \\
\hline Berehat & 152 & 50.7 \\
\hline Mengambil angin & 157 & 52.3 \\
\hline Berkelah & 138 & 46.0 \\
\hline Makan/minum di tepi pantai & 98 & 32.7 \\
\hline Kerja & 21 & 70 \\
\hline $\begin{array}{l}\text { Riadah/bermain sukan air } \\
\text { laut }\end{array}$ & 108 & 36.0 \\
\hline
\end{tabular}

= 300 responden, pelbagai jawaban dibenarkan.

sumber: Kerja lapangan, 2018.

Di samping itu, aktiviti riadah/bermain sukan air laut merupakan salah satu aktiviti utama pelancong. Terdapat beberapa jenis aktiviti sukan air yang menjadi pilihan mereka. Responden paling banyak memilih aktiviti bermain Banana boat iaitu sebanyak $24.0 \%$ (71) dan ini diikuti dengan jet ski 22.7\% (68). Hanya sebilangan kecil responden memilih Big Donut dan Long Boat yang agak lasak iaitu $8.0 \%$ (24) dan $6.0 \%$ (18) sebagai aktiviti sukan laut. Selain sukan laut, aktiviti menunggang kuda dan payung terjun juga digemari, dengan masing-masing sebanyak 13.0\% (39) dan $10.3 \%$ (31) pelancong memilih aktiviti ini. Kepelbagaian aktiviti ini menurut pandangan responden, adalah kerana harganya yang berpatutan dan menjadi ikutan semasa.

\section{Persekitaran semulajadi sebagai asas pantai pelancongan mesra keluarga}

Dalam penarafan sesebuah pantai pelancongan mesra keluarga, terdapat keperluan untuk mempastikan pantai ini memenuhi kriteria yang ditetapkan oleh pihak pemegang taruh. Salah satu daripadanya ialah persekitaran semulajadi pantai. Daripada dapatan kajian, empat dimensi utama dalam persekitaran pantai Batu Feringgi ialah persekitaran fizikal pantai dan pasir, air laut, persekitaran pantai dan keistimewaan pantai. Paling menjadi keutamaan pelancong ialah keistimewaan pantai yang mencapai min 3.80, satu angka yang jauh mendominasi persekitaran semula jadi pantai yang lain (jadual 4). Para pelancong juga memberikan persetujuan peri pentingnya fizikal pantai dan pasir selain daripada fizikal air laut.

Jadual 4. Faktor Fizikal Semula jadi secara menyeluruh

\begin{tabular}{lccc}
\hline Faktor Persekitaran Semula jadi & Min & Aras & Rank \\
\hline Fizikal pantai dan pasir & 3.41 & Sederhana & 3 \\
Fizikal air laut & 3.40 & Sederhana & 4 \\
Persekitaran pantai & 3.45 & Sederhana & 2 \\
Keistimewaan pantai & 3.80 & Sederhana tinggi & 1 \\
\hline
\end{tabular}


Sementara itu jadual 5 memperincikan fizikal pantai dan pasir. Komponen fizikal pantai 'sesuai untuk aktiviti riadah' mencatatkan skor min paling tinggi iaitu 3.92, diikuti 'pantai cantik dan menarik' iaitu skor min sebanyak 3.76. Responden memilih berkecuali/ neutral bagi komponen 'landai dan tidak dalam' iaitu 45.7\%. Ini kerana daripada pemerhatian, air laut di pinggir pantai sememangnya tidak dalam dan ini bersesesuaian dengan keperluan anggota keluarga bermandi-manda dan bermain ombak.

Jadual 5. Fizikal pantai dan pasir

\begin{tabular}{lcccccccc}
\hline Perkara & $\mathbf{1}$ & $\mathbf{2}$ & $\mathbf{3}$ & $\mathbf{4}$ & $\mathbf{5}$ & Min & SP & Rank \\
\hline Landai dan tidak dalam & $4(1.3)$ & $21(7.0)$ & $137(45.7)$ & $123(41.0)$ & $15(5.0)$ & 3.41 & .751 & 3 \\
Stabil dan tiada hakisan & $4(1.3)$ & $55(18.3)$ & $135(45.0)$ & $90(30.0)$ & $16(5.3)$ & 3.20 & .845 & 5 \\
Bersih & $7(2.3)$ & $48(16.0)$ & $130(43.3)$ & $90(30.3)$ & $25(8.3$ & 3.26 & .907 & 4 \\
Cantik dan menarik & $5(1.7)$ & $8(2.7)$ & $90(30.0)$ & $147(49.0)$ & $50(16.7)$ & 3.76 & .818 & 2 \\
$\begin{array}{l}\text { Putih } \\
\text { Tidak tercemar bahan }\end{array}$ & $11(3.7)$ & $45(15.0)$ & $150(50.0)$ & $72(24.0)$ & $22(7.3)$ & 3.16 & .898 & 6 \\
$\begin{array}{l}\text { terampai dan longgokan } \\
\text { sampah }\end{array}$ & $10(3.3)$ & $59(19.7)$ & $128(42.7)$ & $83(27.7)$ & $20(6.7)$ & 3.15 & .924 & 7 \\
$\begin{array}{l}\text { Sesuai untuk aktiviti riadah } \\
\text { Min keseluruhan }\end{array}$ & $5(1.7)$ & & & & & & & \\
\hline
\end{tabular}

Nota: (1) Sangat tidak setuju, (2) Tidak setuju, (3) Neutral/ Berkecuali, (4) Setuju, (5) Sangat Setuju Sumber: Kajian lapangan, 2018

Sebahagian besar pelancong memilih untuk berkecuali, bersetuju dan sangat bersetuju bagi 'pantai tidak tercemar' dan hanya 3.3\% (10) responden memilih sangat tidak setuju. Ini kerana menurut responden, kawasan pantai sering dibersihkan oleh pihak berkuasa tempatan bagi memastikan pantai ini sentiasa tiada longgokan serpihan kayu dan dahan'. Bagi komponen 'bersih' pula, sebanyak 43.3\% (130) responden bagaimanapun memilih untuk berkecuali dan begitu juga dengan keadaan pasir pantai yang putih. Bagi responden, kedua-dua aspek ini agak relatif sebagai tarikan pantai kepada pihak awam. Rajah 2 menunjukkan fizikal pantai ataupun pasir pantai yang terdapat di Pantai Batu Ferringhi di mana terdapat kanak-kanak sedang bermain pasir sewaktu menjalankan aktiviti berkelah bersama ahli keluarga.

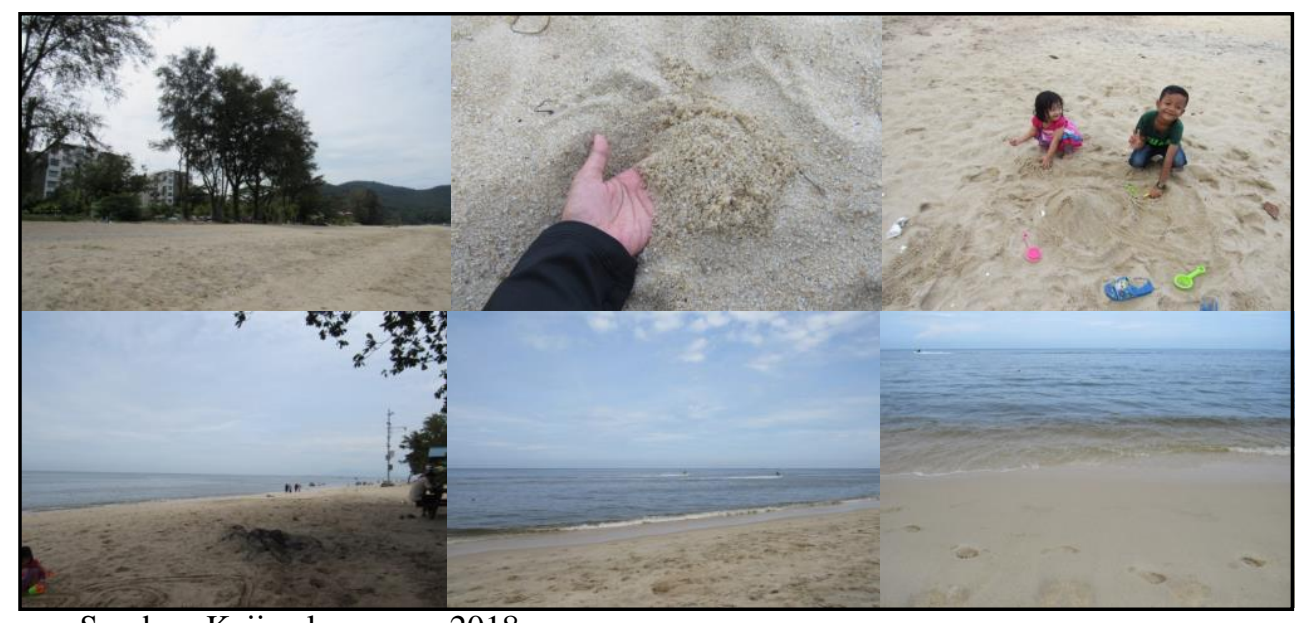

Sumber: Kajian lapangan, 2018

Rajah 2. Fizikal pantai, pasir dan air laut Pantai Batu Feringghi 
Jadual 6 menunjukkan penilaian responden terhadap persekitaran pantai yang mencatat min keseluruhannya 3.41. Skor min paling tinggi adalah 'kawasan persekitaran pantai menarik dan mendamaikan' iaitu 3.83 dengan sebanyak 59.7\% (179) responden bersetuju dengan penyataan ini. Persekitaran pantai berada dalam keadaan selamat mencatat skor min kedua tertinggi iaitu 3.75, di mana sebanyak 47.7\% (143) responden bersetuju bahawa pantai ini berada dalam keadaan selamat. Pada pengamatan pelancong, terdapat pengawal pantai yang sentiasa memantau keselamatan awam dari menara keselamatan dan rondaan berkala dilakukan sekitar pantai. Terdapat juga beach boy yang prihatin terhadap pengunjung yang berada di pantai walaupun mereka mengendalikan aktiviti sukan air/laut.

Jadual 6. Persekitaran pantai

\begin{tabular}{|c|c|c|c|c|c|c|c|c|}
\hline Perkara & 1 & 2 & 3 & 4 & 5 & Min & SP & Rank \\
\hline Menarik dan mendamaikan & $4(1.3)$ & $9(3.0)$ & $65(21.7)$ & $179(59.7)$ & $\begin{array}{c}43 \\
(14.3)\end{array}$ & 3.83 & .756 & 1 \\
\hline $\begin{array}{l}\text { Berada dalam keadaan } \\
\text { selamat }\end{array}$ & $4(1.3)$ & $12(4.0)$ & $90(30.0)$ & $143(47.7)$ & $\begin{array}{c}51 \\
(17.0)\end{array}$ & 3.75 & .831 & 2 \\
\hline $\begin{array}{l}\text { Mempunyai penjaga } \\
\text { keselamatan pantai }\end{array}$ & $6(2.0)$ & $41(13.7)$ & $103(34.3)$ & $130(43.3)$ & $20(6.7)$ & 3.39 . & .876 & 4 \\
\hline $\begin{array}{l}\text { Kawasan perkelahan yang } \\
\text { bersih dan terjaga }\end{array}$ & $7(2.3)$ & $42(14.0)$ & $115(38.3)$ & $106(35.3)$ & $30(10.0)$ & 3.37 & .925 & 5 \\
\hline Dipenuhi tumbuhan hijau & $4(1.3)$ & $28(9.3)$ & $131(43.7)$ & $118(39.3)$ & $19(6.3)$ & 3.40 & .797 & 5 \\
\hline $\begin{array}{l}\text { Landskap pantai yang cantik } \\
\text { dan menarik }\end{array}$ & $4(1.3)$ & $22(7.3)$ & $92(30.7)$ & $151(50.3)$ & $31(10.3)$ & 3.61 & .821 & 3 \\
\hline $\begin{array}{l}\text { Mempunyai kehidupan marin } \\
\text { dan fauna yang menarik }\end{array}$ & $7(2.3)$ & $46(15.3)$ & $122(40.7)$ & $100(33.3)$ & $25(8.3)$ & 3.30 & .909 & 7 \\
\hline $\begin{array}{l}\text { Tiada pencemaran udara dan } \\
\text { air }\end{array}$ & $\begin{array}{c}34 \\
(11.3)\end{array}$ & $61(20.3)$ & $109(36.3)$ & $72(24.0)$ & $24(8.0)$ & 2.97 & $\begin{array}{c}1.10 \\
4\end{array}$ & 9 \\
\hline Tidak padat pengunjung & $\begin{array}{c}18 \\
(6.0)\end{array}$ & $56(18.7)$ & $129(43.0)$ & $78(26.0)$ & $19(6.3)$ & 3.08 & .968 & 8 \\
\hline
\end{tabular}

Min Keseluruhan

3.41

Nota: (1) Sangat tidak setuju, (2) Tidak setuju, (3) Neutral, (4) Setuju, (5) Sangat Setuju

Sumber: Kajian lapangan 2018

Sebanyak 50.3\% (151) responden setuju bahawa landskap pantai ini cantik dan menarik. Ini kerana terdapatnya tumbuhan dan pokok-pokok di sekitar pantai. Skor min paling rendah pula adalah 2.97 iaitu 'tiada pencemaran air dan udara di pantai ini'. Sebanyak $36.3 \%$ pelancong memilih untuk menjawab berkecuali atau neutral tentang perkara ini. Bagi mereka, pencemaran udara akibat kepesatan pembangunan dan perindustrian di negeri ini juga agak lumrah dalam kalangan pengunjung atau pelancong.

Sementara itu jadual 7 menunjukkan keistimewaan pantai dengan skor min keseluruhan tertinggi iaitu 3.80. Pantai ini disifatkan sebagai kawasan yang sesuai untuk melakukan aktiviti riadah. Ini kerana di Pantai Batu Ferringhi, terdapat aktiviti sukan air, bola tampar, menunggang kuda yang sememangnya sesuai untuk kegunaan riadah. 'sesuai untuk kegunaan riadah' adalah mencatat skor min tertinggi iaitu 4.06. Responden yang bersetuju dengan kenyataan tersebut juga tinggi iaitu sebanyak 59.7\% (179).

Kedudukan pantai berdekatan dengan pusat perniagaan seperti medan selera, pusat produk pelancongan, tempat penginapan dan tarikan pelancong seperti muzium, menduduki rank kedua sebagai keistimewaan lokasi pantai. Sebanyak 45.3\% (136) responden setuju dengan kenyataan tersebut. Dalam pada itu sebanyak 36.3\% (119) responden sangat bersetuju bahawa 
terdapatnya 'Night Market' di sepanjang jalan pantai ini sebagai tarikan kenapa mereka memilih lokasi ini. Sebanyak 42.0\% (126) responden setuju terdapat keistimewaan di pantai ini terletak kepada aktiviti menunggang kuda. Kesemua keistimewaan yang terdapat di pantai ini dapat menjadi salah satu tarikan kepada para pelancong dan pengunjung.

Jadual 7. Keistimewaan pantai

\begin{tabular}{|c|c|c|c|c|c|c|c|c|}
\hline Perkara & 1 & 2 & 3 & 4 & 5 & Min & SP & Rank \\
\hline Sesuai untuk kegunaan riadah & $4(1.3)$ & $9(3.0)$ & $65(21.7)$ & $179(59.7)$ & $43(14.3)$ & 4.06 & .756 & 1 \\
\hline $\begin{array}{l}\text { Lokasi pantai mudah dikunjungi dan } \\
\text { strategik }\end{array}$ & $4(1.3)$ & $12(4.0)$ & $90(30.0)$ & $143(47.7)$ & $51(17.0)$ & 3.75 & .831 & 5 \\
\hline Pantai tiada ancaman tsunami & $53(17.7)$ & $84(28.0)$ & $86(28.7)$ & $51(17.0)$ & $26(8.7)$ & 2.71 & 1.193 & 6 \\
\hline $\begin{array}{l}\text { Kedudukan pantai berdekatan dengan } \\
\text { pusat perniagaan seperti medan selera, } \\
\text { penginapan, dan tarikan pelancongan, }\end{array}$ & $9(3.0)$ & $5(1.7)$ & $54(18.0)$ & $136(45.3)$ & $96(32.0)$ & 4.02 & .916 & 2 \\
\hline $\begin{array}{l}\text { Terdapat 'Night Market' di sepanjang } \\
\text { jalan dengan barangan harga } \\
\text { berpatutan. }\end{array}$ & $10(3.3)$ & $17(5.7)$ & $47(15.7)$ & $117(39.0)$ & $119(36.3)$ & 3.99 & 1.025 & 3 \\
\hline $\begin{array}{l}\text { Terdapat aktiviti menunggang kuda di } \\
\text { sekitar pantai pada waktu petang }\end{array}$ & $9(3.0)$ & $16(5.3)$ & $61(20.3)$ & $126(42.0)$ & $88(29.3)$ & 3.89 & .986 & 4 \\
\hline Min Keseluruhan & & & & & & 3.80 & & \\
\hline
\end{tabular}

Nota: (1) Sangat tidak setuju, (2) Tidak setuju, (3) Neutral/ Berkecuali, (4) Setuju, (5) Sangat Setuju

Sumber: Kajian lapangan, 2018

\section{Kesimpulan}

Pantai merupakan tumpuan pelancong keluarga yang terdiri daripada pelbagai latar dan corak penggunaannya. Berdasarkan penilaian pelancong keluarga terhadap persekitaran fizikal semula jadi sebagai asas pembangunan pantai pelancongan mesra keluarga didapati keistimewaan pantai menjadi keutamaan mereka. Hal ini kerana nilai min bagi keseluruhan dimensi persekitaran fizikal mencapai min 3.80. Persekitaran fizikal semulajadi ternyata merupakan dimensi yang dititkberatkan oleh pelancong keluarga kerana ia berkait dengan aktiviti rekreasi lasak dan senggang yang dapat mereka lakukan. Pantai yang landai dan ombak yang tidak terlalu kuat membolehkan ahli keluarga bebas melakukan aktiviti riadah.

Dapatan kajian ini juga seiring dengan kajian-kajian di negara maju, dan ini mengesahkan lagi keperluan mewujudkan kriteria pantai pelancongan mesra keluarga di negara ini. Kepentingan ciri fizikal pantai yang merangkumi sifat fizikal pantai, air laut dan persekitaran pantai perlu menjadi bahagian penting dalam pengurusan pantai. Para pelancong juga mencadangkan agar beberapa penambahbaikan dilakukan bagi memelihara keindahan fizikal dan persekitaran pantai ini. Ini termasuk jaminan pantainya bersih dan luas, air lautnya tidak tercemar, jaminan keselamatan pantai dan landskap pantai yang terpelihara. Melalui maklumat ini, pihak berkepentingan dapat merancang program kesedaran awam tentang peri pentingnya persekitaran fizikal semulajadi dijaga dan dipulihara agar pengunjungnya dapat menikmati kelebihan ini apabila bercuti di pantai ini. Kesimpulannya, persekitaran fizikal semulajadi berperanan penting dalam menarik minat pengunjung atau pelancong keluarga untuk melancong ke pantai peranginan khususnya di Pantai Batu Ferringhi. 


\section{Penghargaan}

Penyelidikan ini dibiayai oleh Kementerian Pelajaran Malaysia di bawah dana penyelidikan fundamental FRGS/1/2015/SS07/UKM/02/1 bertajuk Pembinaan Kerangka Penilaian Pantai Pelancongan Mesra Keluarga.

\section{Rujukan}

Ahmad Nazrin Aris Anuar, Habibah Ahmad, Hamzah Jusoh, Mohd Yusof Hussain, Amriah Buang, \& Sri Winarni Samsir. (2014). Pembentukan destinasi mesra pelancong berasaskan perspektif pelancong domestik. Geografia-Malaysian Journal of Society and Space, 10(8), $1-12$.

Botero, C., Anfuso, A., Williams, A.T., Zielinski, S., Silva, C.P., Cervantes, O., Silva, L., \& Cabrera, J.A. (2013). Reasons for beach choice: European and Caribbean perspectives Journal of Coastal Research, 65(1), 880-885.

Cervantes, O., Espejel, I., Arellano, E., \& Delhumeau, S. (2008). Users' perception as a tool to improve urban beach planning and management. Environmental Management, 42, 249264.

Cicin-Sain, B., Knecht, R.W., \& Fisk, G.W. (1995). Growth in capacity for integrated coastal management since UNCED: an international perspective. Ocean Coast Manage, 29, 93123.

Cutter, S.L., Nordstrom, K.F., \& Kuema, G.A. (1979). Social and environmental factors influencing beach site selection. In Proc. 5th Ann. Conf. Resource allocation issues in the coastal environment, (ed.), N. West, 183-194, The Coastal Society, USA.

Dornisch, V.D., Ankersen, T.T., \& Swett, R.A. (2015). Florida beach users' perceptions of beach ownership, erosion management, and sea level rise. University of Florida Conservation Clinic, University of Florida Levin College of Law

Ergin, A., Williams, A.T., \& Micallef, A. (2006). Coastal scenery: appreciation and evaluation. Journal of Coastal Research, 22(4), 958-964.

Habibah Ahmad \& Hamzah Jusoh. (2018). Family-friendly beach tourism in Malaysia: whither physical or man-made determinants. 7th RSEP International Social Sciences Conference Proceeding, 141-168.

Habibah Ahmad (2007). Percutian Famili Keluarga Melayu. tesis Phd UKM. (tidak diterbitkan)

Habibah Ahmad. (2002). Peranan percutian famili ke arah pembentukan keluarga bahagia. Prosiding SKIM 8 'Pembangunan Manusia di Indonesia dan Malaysia'. 8-10 Oktober. UKM, Bangi.

Hall, C.M. (2001). Trends in ocean and coastal tourism: the end of the last frontier? Ocean \& Coastal Management, 44, 601-618.

Harifah Mohd Noor, Rosmiza Mohd Zainal, New Gaik Ling, Jabil Mapjabil, Ruzila Ismail, Badariah Ab Rahman \& Mohd Jirey Kumalah. (2015). Faktor budaya dan bukan budaya dalam mempengaruhi lawatan ulangan: Kajian kes pelancong asing Pulau Pinang. Geografia-Malaysia Journal of Society and Space, 11(12), 52-63.

Honey, M., \& Krantz, D.M.A. (2007). Global trend in coastal tourism. Centre on Ecotourism and Sustainability Development, A non-profit research organization. Stanford University \& Washington D.C.

Houser, C., Murphy, T., \& Labude, D. (2015). Alongshore correspondence of beach users and rip channels at wales Beach, Florida. Natural Hazards, 78(3), 2175-2183. 
Jamaluddin MD Jahi (2009). Pembangunan pelancongan dan impaknya terhadap persekitaran fizikal pinggir pantai Malaysian. Journal of Environmental Management, 10(2), 71-88.

James, R.J. (2000). From beaches to beach environments: Linking the ecology, human-use and management of beaches in Australia. Ocean and Coastal Management, 43, 495-514.

Jędrzejczak, M.F. (2004). The modern tourist's perception of the beach: Is the sandy beach a place of conflict between tourism and biodiversity? Coastline Reports. 2. 109-119.

Johan Afendi Ibrahim \& Mohamad Zaki Ahmad. (2011). Pelancongan Langkawi 1987-2010: Pencapaian dan cabaran masa depan. Prosiding PERKEM VI, Jilid I (2011), 602-613.

Johan Afendi Ibrahim, Norhanim Abdul Razak \& Mohamad Zaki Ahmad. (2012). Impak pembangunan pelancongan terhadap destinasi pantai. Kajian kes: Pantai Cenang, Langkawi. Prosiding PERKEM VII, Jilid I (2012), 601-610.

Kadaruddin Aiyub. (1997). Penggunaan dan pengurusan zon pinggir pantai Negeri Sembilan. Akademika, 50(Januari), 3-23.

Kerajaan Negeri Pulau Pinang. (2013). https://www.penang.gov.my/ [12 Januari 2018]

Lozoya, J.P., Sardá, R., \& Jiménez, J. (2014). Users expectations and the need for differential beach management frameworks along the Costa Brava: Urban vs. natural protected beaches. Land Use Policy, 38, 397-414.

Maguire, G.S., Miller, K.K., Weston, M.A., \& Young, K. (2011). Being beside the seaside: Beach use and preferences among coastal residents of south-eastern Australia. Ocean \& Coastal Management, 54, 781-788.

Minuchin, P. (1985). Families and individual development: Provocations from the field of family therapy. Child Development, 5(6), 289-302.

Mohd. Anuar Md. Amin. (2009). Faktor tarikan pelancongan pantai: Kajian kes di pantai Port Dickson, Negeri Sembilan. Prosiding PERKEM IV, Jilid 2, 243-254.

Mohd. Azlan Abdullah, Noraziah Ali, Rosniza Aznie Che Rose, Mohd Fuad Mat Jali, \& Azahan Awang. (2012). Industri pelancongan dan alam sekitar di Port Dickson: Menyorot titik keseimbangan antara permintaan dan penawaran. Geografia-Malaysia Journal of Society and Space, 8(7), 135-146.

Morgan, R., Jones, T.C., \& Williams, A.T. (1993). Opinions and perceptions of England and Wales Heritage Coast beach users: some management implications from the Glamorgan Heritage Coast, Wales. Journal of Coastal Research, 9, 1083-1093.

Onofri, L., \&, Nunes, P.A.L.D. (2013) Beach 'lovers' and 'greens': A worldwide empirical analysis of coastal tourism. Ecological Economics, 88, 49-56.

Penang Geographic Information centre. (2018). http://pegis.penang.gov.my/ [20 Mac 2018]

Portal Penang Global Tourism. (2018). http://mypenang.gov.my/contact-us. data pelancongan [1 Mei 2018].

Ramali Yusoff. (2017). Faktor tarikan pelancongan pantai: Kajian kes di Pantai Irama Bachok, Kelantan: Proceedings ICE 2017, 480 - 492

Roca, E., Riera, C, Villares, M.A, Fragell, R., \& Junyent, R.A. (2008). Combined assessment of beach occupancy and public perceptions of beach quality: A case study in the Costa Brava, Spain. Ocean \& Coastal Management, 51, 839-846.

Sarda, R., Mora, J., Ariza, E., Avila, C., \& Antonio Jimenez, J. (2009). Decadal shifts in beach user sand availability on the Costa Brava (Northwestern Mediterranean Coast). Tourism Management, 30, 158-168.

Staines, C., \& Ozanne-Smith, J. (2002). Feasibility of identifying family friendly beach along Victoria's Coastline. Accident Research Centre. Monash University. 
Williams, A.T., Gardner, W., Jones, T.C., Morgan, R., \& Ozhan, E. (1993). A psychological approach to attitudes and perceptions of beach users: implications for coastal zone management. The first international conference on the Mediterranean coastal environment, MEDCOAST'93, Antalya, Turkey, 217-228.

Williamson, A., Hatfield, J., Sherker, S., Brander, R., \& Hayen, A. (2012). A comparison of attitudes and knowledge of beach safety in Australia for beachgoers, rural residents and international tourists. Australia New Zealand Journal of Public Health, 36(4), 385-391.

Wolch, J., \& Zhang, J. (2004). Beach recreation, cultural diversity and attitudes toward nature. Journal of Leisure Research, 36(3), 414-443. 